\title{
Geochemical Characteristics and Microbial Community Composition in Toxic Metal-Rich Sediments Contaminated with Au-Ag Mine Tailings
}

\author{
Man Jae Kwon ${ }^{\mathrm{a}^{*}}$, Jung-Seok Yang ${ }^{\mathrm{a}^{*}}$, Seunghak Lee ${ }^{\mathrm{b}}$, Giehyeon Lee ${ }^{\mathrm{c}}$, Baknoon Ham ${ }^{\mathrm{a}}$, \\ Maxim I. Boyanov ${ }^{\mathrm{d}, \mathrm{e}}$, Kenneth M. Kemner ${ }^{\mathrm{d}}$, and Edward J. O’Loughlin ${ }^{\mathrm{d}}$
}

\footnotetext{
${ }^{\text {a }}$ Korea Institute of Science and Technology, Gangneung, KOREA

${ }^{\mathrm{b}}$ Korea Institute of Science and Technology, Seoul, KOREA

${ }^{\mathrm{c}}$ Yonsei University, Seoul, KOREA

${ }^{\mathrm{d}}$ Biosciences Division, Argonne National Laboratory, Argonne, IL, USA

${ }^{\mathrm{e}}$ Bulgarian Academy of Sciences, Institute of Chemical Engineering, Sofia, Bulgaria
}

*Corresponding Author: Korea Institute of Science and Technology, Gangneung, KOREA, 679

Saimdangro, Gangneung, Gangwon-do, 210-340, Korea, Phone: +82-33-650-3705; Fax: +82-33-650-

3729; mkwon@kist.re.kr; yjseok@gmail.com

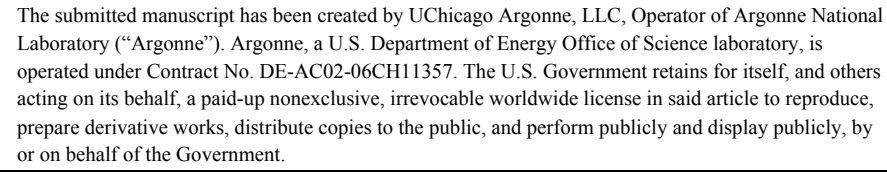

The submitted manuscript has been created by UChicago Argonne, LLC, Operator of Argonne National Laboratory ("Argonne”). Argonne, a U.S. Department of Energy Office of Science laboratory, is operated under Contract No. DE-AC02-06CH11357. The U.S. Government retains for itself, and others acting on its behalf, a paid-up nonexclusive, irrevocable worldwide license in said article to reproduce, prepare derivative works, distribute copies to the public, and perform publicly and display publicly, by or on behalf of the Government.

A manuscript submitted to Journal of Hazardous Materials

March 2015 


\begin{abstract}
The effects of extreme geochemical conditions on microbial community composition were investigated for two distinct sets of sediment samples collected near weathered mine tailings. One set $(\mathrm{SCH})$ showed extraordinary geochemical characteristics: As (6.7-11.5\%), $\mathrm{Pb}(1.5-2.1 \%), \mathrm{Zn}(0.1-0.2 \%)$, and $\mathrm{pH}(3.1-3.5)$. The other set (SCL) had As (0.3-1.2\%), $\mathrm{Pb}(0.02-0.22 \%)$, and $\mathrm{Zn}(0.01-0.02 \%)$ at $\mathrm{pH}$ 2.5-3.1. The bacterial communities in SCL were clearly different from those in SCH, suggesting that extreme geochemical conditions affected microbial community distribution even on a small spatial scale. The clones identified in SCL were closely related to acidophilic bacteria in the taxa Acidobacterium (18\%), Acidomicrobineae (14\%), and Leptospirillum (10\%). Most clones in SCH were closely related to Methylobacterium (79\%) and Ralstonia (19\%), both well-known metal-resistant bacteria. Although total As was extremely high, over $95 \%$ was in the form of scorodite $\left(\mathrm{FeAsO}_{4} \cdot 2 \mathrm{H}_{2} \mathrm{O}\right)$. Acid-extractable As was only $\sim 118$ and $\sim 14 \mathrm{mg} \mathrm{kg}^{-1}$ in SCH and SCL, respectively, below the level known to be toxic to bacteria. Meanwhile, acid-extractable $\mathrm{Pb}$ and $\mathrm{Zn}$ in $\mathrm{SCH}$ were above toxic concentrations. Because As was present in an oxidized, stable form, release of $\mathrm{Pb}$ and/or $\mathrm{Zn}$ (or a combination of toxic metals in the sediment) from the sediment likely accounts for the differences in microbial community structure. The results also suggest that care should be taken when investigating mine tailings, because large differences in chemical/biological properties can occur over small spatial scales.
\end{abstract}

Key words: Mine tailings; Toxic metals; Microbial community; Scorodite 


\section{Introduction}

Mining activities and their resulting wastes (e.g., mine tailings) have created widespread pollution in many locations around the world. For example, enormous amounts of mine wastes from the abandoned Songcheon Au-Ag mine, Gangneung, South Korea, have contaminated the soil and groundwater in the vicinity, leading to high levels of toxic heavy metals including As (up to $10 \mathrm{wt} \%$ ), $\mathrm{Pb}$, $\mathrm{Zn}$, and $\mathrm{Cu}$.

Arsenic is commonly found in high concentrations in mine tailings because of its natural occurrence in $\mathrm{Ag}$ and $\mathrm{Au}$ ores and the surrounding bedrock. It is of particular concern because of its established toxicity in the environment [1]; however, several known bacteria and archaea are able to tolerate arsenate levels up to 40-50 mM [2-4]. Microorganisms can tolerate toxic metal ions because of resistance systems encoded in bacterial plasmids. For example, some bacteria possess As resistance efflux systems consisting of two enzymes, $\operatorname{ars} \mathrm{A}$ and $\operatorname{ars} \mathrm{B}$, for $\mathrm{As}(\mathrm{III})$ transportation and one enzyme, $\operatorname{ars} \mathrm{C}$, for reducing intracellular $\mathrm{As}(\mathrm{V})$ to less toxic $\mathrm{As}(\mathrm{III})[5,6]$.

Excess $\mathrm{Zn}$ is also well known to be harmful to various organisms. $\mathrm{Zn}$ ions in aqueous solution are highly toxic to bacteria [7], algae [7], plants [8], and invertebrates [9]. A recent study suggested that $\mathrm{Zn}(\mathrm{II})$ toxicity to bacteria is mediated by extracellular cation competition, particularly with $\mathrm{Mn}$ (II) [10]. Toxicity of other heavy metals (e.g., $\mathrm{Pb}$ and $\mathrm{Cu}$ ) to bacteria has also been investigated extensively [11-13].

Combinations of one, two, or more heavy metals have shown different toxicologic responses in bacteria via synergism and antagonism. Most mine tailings sites, including the Songcheon weathered mine tailings, contain multiple toxic elements, and it is difficult to evaluate which metal(s) are responsible for bacterial abundance or resistance in environments with multiple metal contaminants. In spite of such limitation, stress associated with toxic metals is known to change or decrease microbial community diversity [14]. However, little is known of the indigenous microbial communities in mine tailings contaminated with extremely high concentrations of toxic metals. 
This study investigated the effects of extreme geochemical conditions on microbial community composition in contaminated sediments, to (1) investigate the geochemical characteristics of sediments extremely rich in heavy metals in weathered mine tailings of the abandoned Songcheon $\mathrm{Au}-\mathrm{Ag}$ mine, (2) determine the major mineral phases (including heavy metals) in the sediments, (3) identify the dominant microbial communities in such extreme environments, and (4) determine the factors controlling the composition of the indigenous microbial communities. Two distinct sets of sediment samples from the mine tailings near the abandoned Songcheon mine sites were collected to compare the microbial community compositions from environments rich in toxic metals and relatively poor in toxic metals. The analytical techniques used to investigate the geochemical characteristics and microbial community compositions in the contaminated sediments included synchrotron-based X-ray techniques and clone library construction, as well as terminal restriction fragment length polymorphism (T-RFLP) analysis.

\section{Material and methods}

\subsection{Study area and sampling method}

Songcheon mine is located in the northern part of Gangneung city, South Korea (Fig. 1). The predominant geology of the area is Precambrian felsic gneiss. The hydrothermal deposits of Songcheon mine are composed of $\mathrm{Au}$ and Ag minerals in quartz veins, with sulfide minerals including arsenopyrite, pyrite, galena, and sphalerite. The mine was active from 1939 until its closure in 1977. However, large amounts of mine waste, rock ore dumps, and mine tailings were left behind without proper environmental protection. The high levels of toxic metals present in the tailings, resulting from Au processing techniques employed at the time, constitute a long-term source of toxic metal release to the environment and impacted ecosystems in the Songcheon area [15].

Four samples from Songcheon mine tailings and two samples from surrounding soils were collected in August 2011. The unsaturated sediment samples from the mine tailings were collected 5-10 m apart. A block of sediment (approximately $5 \mathrm{~cm} \times 5 \mathrm{~cm} \times 5 \mathrm{~cm}$ ) from the mine tailing area was brought to 
the laboratory and further divided into two parts on the basis of apparent color differences (7.5YR 7/0 [SCH1-4] vs. 10YR 5/3 [SCL1-4]) by using sterilized razors. The color was measured with the Munsell soil color chart. Two samples of unsaturated soil unaffected by mine tailings were also collected from the mountain and agricultural lands and designated as control samples SCB-1 and SCB-2, respectively. The samples were collected with a stainless steel shovel after removal of the overlying $10 \mathrm{~cm}$ of topsoil.

\subsection{Chemicals}

All chemicals used were of reagent grade quality or higher. Distilled deionized water $\left(\mathrm{ddH}_{2} \mathrm{O}\right)$ prepared with a Millipore water purification system (Barnstead, USA) was used throughout. All the analytical procedures have been validated by using certified and/or internal reference materials.

\subsection{Physical, chemical, and mineralogical analyses}

Details on analytical methods for physical, chemical, and mineralogical characterization of sediment samples are in the Supporting Information. Briefly, the size distribution of the soils was analyzed according to ASTM Standard D402. Loss on ignition (LOI) was determined gravimetrically. The concentrations of major and trace elements in bulk samples were determined by wavelengthdispersive X-ray fluorescence (XRF). The fractionation of metals in the soils was determined by modification of the Standards, Measurements and Testing Programme of the European Commission (a continuation of the BCR and Measurements and Testing Programmes) sequential extraction procedure [16, 17] (Table $\mathrm{S} 1$ ). Concentrations of $\mathrm{As}, \mathrm{Zn}, \mathrm{Pb}, \mathrm{Cu}, \mathrm{Ni}$, and $\mathrm{Cd}$ were determined by inductively coupled plasma optical emission spectrometry (Varian 730-ES, USA).

Surface analysis of the samples was conducted with environmental scanning electron microscopy (ESEM; FEI XL-30 FEG) with an EDAX Gemini energy-dispersive X-ray (EDX) spectrometer. 
X-ray powder diffraction (XRD) analysis was conducted by using an X'Pert Pro MPD X-ray

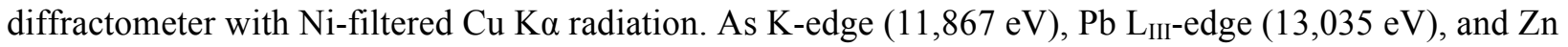
K-edge $(9,659 \mathrm{eV}) \mathrm{X}$-ray absorption near-edge (XANES) and extended X-ray absorption fine structure (EXAFS) spectra were collected at room temperature at the MRCAT/EnviroCAT beamline, sectors 10BM and 10-ID, Advanced Photon Source, Argonne National Laboratory, Illinois, USA.

\subsection{Microbial community analysis}

Samples for microbial community analysis were frozen at $-80^{\circ} \mathrm{C}$ until the experiments were completed. Details on the methods for microbial community analysis are in Supporting Information. Briefly, total genomic DNA was extracted by using an i-genomic Soil DNA Extraction Mini Kit (iNtRON, S. Korea) and was quantified by using a Qubit fluorometer (Invitrogen, USA).

For T-RFLP analysis, the $16 \mathrm{~S}$ rDNA extracted was amplified by polymerase chain reaction (PCR) with FAM(6-carboxyfluorescein)-labeled Eubacterial primer 8F (5'-/56FAM/AGAGTTTGATYMTGGCTCAG-3') and universal primer 1492R (5'TACGGYTACCTTGTTACGACTT-3'). T-RFLP was performed as described by Liu et al. [18] with restriction enzymes HhaI and MspI (New England Biolabs). The digests were analyzed by using an automated sequencer (Macrogen, Seoul, S. Korea), and Peak Scanner ${ }^{\mathrm{TM}}$ Software v1.0 (Applied Biosystems Instruments, Foster City, CA) was used to produce electropherograms showing the abundance and lengths of the fluorescently labeled terminal fragments.

To identify the true microbial community structure, statistical methods were used for characterizing the diversity of microbial communities by analysis of T-RFLP of 16S rRNA genes (http://www.ibest.uidaho.edu/tools/trflp_stats/index.php) [19]. Next, a distance matrix was generated with the Bray-Curtis model and a square-root transformation of the relative peak heights by using Primer-6 (PRIMER-E Ltd, UK) to compare the similarity of the T-RFLP peak profiles of the samples over time. This relationship between sample TRF community profiles was then displayed graphically with non- 
metric multidimensional scaling (MDS) to show how the composition shifted with time and with treatment.

For clone library construction and high-throughput sequencing, PCR amplification was conducted with $8 \mathrm{~F}$ and $1492 \mathrm{R}$ primers. For amplification of archaeal DNA, primers were 109F (5'ACKGCTCAGTAACACGT-3') and 912R (5'- CTCCCCCGCCAATTCCTTTA-3'). Clone libraries were constructed by using the T-Blunt ${ }^{\mathrm{TM}}$ PCR Cloning Kit (with DH5 $\alpha$ Competent Escherichia coli; Solgent, Korea). Approximately 50 colonies per plate were selected randomly and re-amplified by using the vector-specific primers M13F and M13R. Purified M13 PCR products were sequenced at the Marcrogen (Seoul, Korea). The sequences screened were analyzed versus publicly available bacterial 16S rRNA gene sequences from the Ribosomal Database Project (RDP), Release 11 [20].

\section{Results and discussion}

\subsection{Geochemical characteristics}

The gray-colored SCH sediments showed extraordinary geochemical characteristics, including high concentrations of $\mathrm{As}, \mathrm{Pb}, \mathrm{Cu}, \mathrm{Fe}$, and $\mathrm{S}$ with low $\mathrm{pH}$ and high LOI, while the brown-colored SCL sediments $(\mathrm{n}=4)$ contained much less of these elements and had lower $\mathrm{pH}$ and LOI (Table 1). Background sediments $(\mathrm{SCB}, \mathrm{n}=2)$ unaffected by mine tailings had relatively low concentrations of toxic metals.

The LOI of SCH was almost one order of magnitude higher than that of SCL, suggesting that the SCH sediments included significantly more organic content and/or structural water. LOI has been used widely to estimate the organic and carbonate contents of sediments [21, 22]. The coincident high LOI value and the high toxic metal levels in SCH suggest that a portion of these metals might be adsorbed to or complexed with organic matter. Alternatively, As volatilization during LOI analysis might result in artificially high LOI in SCH. 
The results of sequential extraction show that the first extraction (F1) accounted for only $0.1 \%$ $\left(\sim 118 \mathrm{mg} \mathrm{kg}^{-1}\right)$ and $0.2 \%\left(14 \mathrm{mg} \mathrm{kg}^{-1}\right)$ of $\mathrm{As}$ in SCH and SCL, respectively (Table 2 and Fig. S5), suggesting that As is not easily leachable from the sediment samples. F1 might represent the portion of easily transferrable metals from solid pools to the aqueous phase when rainwater flows through the weathered mine tailings. The transport of toxic metals to surface water and/or groundwater can decrease water quality. Also, the water-soluble fraction is ecologically important, because the metals in this form can be more available for uptake by microorganisms and plants [23]. Low As in the F1 fraction might be due to the speciation of As. In fact, solid-phase As existed mostly as scorodite $\left(\mathrm{FeAsO}_{4} \cdot 2 \mathrm{H}_{2} \mathrm{O}\right)$ (see Section 3.2). Inhibition of As leaching from sediments in the presence of $\mathrm{Fe}$ oxides has been reported previously [1].

Interestingly, As in the F2 fraction (reducible) in SCL (23.9\%) was much higher than that in $\mathrm{SCH}(1.2 \%)$, suggesting that a significant fraction of As in SCL was bound to Fe/Mn oxide phases. Because total Mn concentrations (80 and $170 \mathrm{mg} \mathrm{kg}^{-1}$ in SCH and SCL, respectively) were much smaller than total $\mathrm{Fe}$ (13.1 and 3.9\% in SCH and SCL, respectively), As was most likely bound to Fe oxides rather than Mn oxides [24, 25]. In addition, the higher As levels in the F2-extractable fraction in SCL suggest that some iron leached from SCH by rainwater might be precipitated in SCL as poorly crystalline Fe(III) (hydr)oxides. Although the fraction of poorly crystalline Fe(III) (hydr)oxide phases was not determined in the current study, Fe(III) (hydr)oxides can be formed by the continuous oxidation of ferrous sulfide minerals in mine tailings.

The higher F1 metal concentrations for SCH than for SCL are consistent with the higher concentrations of total metals in SCH (Table 2), as well as higher levels of fines (silts and clays) that provide more sites for sorption of exchangeable metals. F1 metals concentrations in both SCH and SCL samples were in the following order: $\mathrm{Pb}>\mathrm{Zn}>\mathrm{As}>\mathrm{Cu}>\mathrm{Ni}>\mathrm{Cd}$. The $\mathrm{F} 1$ fraction of $\mathrm{Pb}$ in $\mathrm{SCH}$ was relatively low $(0.75 \%)$ (Fig. S5), but the $\mathrm{F} 1$ concentration of $\mathrm{Pb}$ was relatively high $\left(280 \mathrm{mg} \mathrm{kg}^{-1}\right)$ (Table 2). In $\mathrm{SCH}, \mathrm{Pb}$ was most abundant in $\mathrm{F} 2$, suggesting that $\mathrm{Pb}$ was bound to $\mathrm{Fe}$ oxides. A relatively high 
fraction of $\mathrm{Pb}$ compared to other metals was observed in F2 for both $\mathrm{SCH}(54.1 \%)$ and SCL (7.1\%), consistent with the higher sorption affinity of $\mathrm{Pb}$ to $\mathrm{Fe}(\mathrm{III})$ (hydr)oxides than other metals, including $\mathrm{Cu}$, $\mathrm{Zn}, \mathrm{Co}$, and $\mathrm{Cd}$ [26-28]. The $\mathrm{F} 1$ fraction of $\mathrm{Zn}$ in $\mathrm{SCH}$ was relatively high (5.53\%), and the concentration of $\mathrm{Zn}$ was also high (192 $\left.\mathrm{mg} \mathrm{kg}^{-1}\right)$. In $\mathrm{SCH}, \mathrm{Zn}$ was most abundant in $\mathrm{F} 3$ and F4. Relatively high concentrations of $\mathrm{Pb}$ and $\mathrm{Zn}$ compared to other metals in $\mathrm{SCH}$ were found in $\mathrm{F}$ 1, indicating that these metals have the potential for greater mobility to the environment.

\subsection{Mineralogy}

\subsubsection{Environmental scanning electron microscopy}

The ESEM images in Fig. 2 show that particle sizes were smaller in SCH than in SCL, consistent with the particle size analysis (Table 1). Submicron-sized grains in SCH were distributed relatively evenly, while various particle sizes are seen in SCL samples. EDX analysis of As-rich spots showed that, the concentrations of As in SCH were 10-29 wt \%, while those in SCL were 1-4 wt \%. Because the EDX analysis was focused in areas where the As-rich mineral (scorodite) constituted a larger fraction of the sediments, the concentrations of As were higher as measured by EDX than by XRF.

\subsubsection{X-ray powder diffraction}

The XRD patterns indicate that the major crystalline phases of SCH and SCL are quartz $\left(\mathrm{SiO}_{2}\right)$ and scorodite $\left(\mathrm{FeAsO}_{4} \cdot 2 \mathrm{H}_{2} \mathrm{O}\right)(\mathrm{Fig} .3)$, consistent with the results of a previous study [29] showing that the weathered tailings at the site include galena, sphalerite, and pyrite, in addition to quartz and scorodite. Lee et al. [29] suggested that scorodite was formed by the continuous oxidation of As-bearing sulfide minerals such as arsenopyrite. Although scorodite is generally stable, weathering of scorodite in mine tailings can lead to significant mobilization of As and contamination of surrounding environments [29]. 


\subsubsection{X-ray absorption fine structure}

Figure 4 compares the XANES data for the samples and As(III) and As(V) standards. The two valence states of As have clear spectroscopic signatures in the energy position of the absorption edge and the white line (the largest absorption peak after the edge). The spectra from all samples overlie the As(V) standard spectrum, indicating that at least $90-95 \%$ of the As in the solids is present as As(V). All samples show EXAFS spectra identical to that of the scorodite standard (Fig. S1), indicating that over 95\% of total As in the solid phase is present as scorodite. The EXAFS results are consistent with the presence of peaks for scorodite in the XRD pattern of the SCH sample (Fig. 3), establishing scorodite as the predominant As phase at the sampling site ( $>95 \%$ of total As). To the best of our knowledge, this is the first report of quantitative analysis of scorodite in Songcheon mine areas.

Additional EXAFS analyses indicate that $\mathrm{Zn}(\mathrm{II})$ in the SCH sample is predominantly in octahedral geometry. The XANES and EXAFS features suggest that the $\mathrm{Zn}$ (II) species are possibly

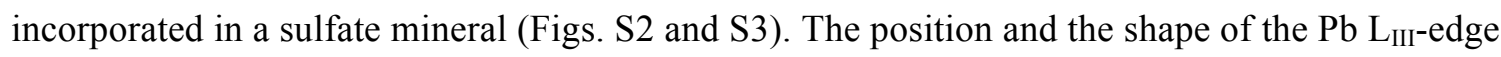
XANES spectrum suggest an O-coordinated $\mathrm{Pb}(\mathrm{II})$ species in the $\mathrm{SCH}$ soil sample (Fig. S4). The data, however, are different from those of the available standards [ $\mathrm{PbO}$, dissolved $\mathrm{Pb}(\mathrm{II}), \mathrm{Pb}(\mathrm{II})$-carbonate, and a $\mathrm{Pb}$ (II) phosphate complex], so a more precise determination of the $\mathrm{Pb}$ (II) species was not possible. Additional details on the $\mathrm{Zn}$ and $\mathrm{Pb}$ mineral phases suggested by the $\mathrm{X}$-ray spectroscopy analysis are in the Supporting Information.

\subsubsection{Leachability of scorodite and environmental significance}

Arsenopyrite (FeAsS) and other As-bearing pyrites in gold deposits can be oxidized to various secondary As minerals (e.g., scorodite, symplesite, pharmacosiderite, arseniosiderite, and yukonite [30]) in near-surface environments [31]. Among these minerals, scorodite is the most common in numerous mine and industrial wastes and tailings, particularly under acidic conditions [32-34]. Scorodite is of particular interest because it effectively immobilizes As, due to its low solubility and dissolution rate [35, 
36]. Many studies investigating the leaching characteristics of natural or synthesized scorodite with varying particle size, reaction time, temperature, Fe(III) (hydr)oxides (e.g., goethite, ferrihydrite), and pH have identified solution $\mathrm{pH}$ as the most important factor controlling the rate and extent of As release [33, 36]. Zhu and Merkel [37] showed that scorodite can dissolve congruently or incongruently, depending on the $\mathrm{pH}$. In the current study, sediment $\mathrm{pH}$ ranged between 2.5 and 3.5. Therefore, the most likely equilibrium equation (Rx. 1) is

$$
\mathrm{FeAsO}_{4} \cdot 2 \mathrm{H}_{2} \mathrm{O}+(x-y) \mathrm{H}^{+}=\mathrm{Fe}(\mathrm{OH})_{y}^{3-y}+\mathrm{H}_{x} \mathrm{AsO}_{4}{ }^{x-3}+(2-y) \mathrm{H}_{2} \mathrm{O}
$$

where $x=2$ or 3 and $y=0$ or 1 at $\mathrm{pH} 2-3.5$.

The solubility of nanocrystalline scorodite was about $0.25 \mathrm{mg} \mathrm{L}^{-1}$ at $\mathrm{pH} 3-4$, but it increased at $\mathrm{pH}<2$ and $\mathrm{pH}>6$ to 20 and $5 \mathrm{mg} \mathrm{L}^{-1}$, respectively [36]. Other studies reported $\sim 0.4 \mathrm{mg} \mathrm{L}^{-1}$ As solubility at $\mathrm{pH} 2.5$ [35] and $\sim 7$ and $\sim 0.1 \mathrm{mg} \mathrm{L}^{-1}$ minimum solubility at $\mathrm{pH} 2.5$ in the presence of goethite and ferrihydrite, respectively [38]. However, the current study indicated that acid-extractable As (F1) was $\sim 118 \mathrm{mg} \mathrm{kg}^{-1}$ in SCH samples, which is much higher than the values reported by others (Table 2). This finding suggests the presence of easily extractable As phases $(<5 \%)$ other than scorodite and/or less crystalline (or nanocrystalline) scorodite in these samples. Recent studies [35, 39] reported a wide range of scorodite solubility — spanning as much as four orders of magnitude for the published solubility products of $\mathrm{Fe}(\mathrm{III})$ arsenates - likely because of the different crystallinities of the samples investigated; crystalline scorodite is approximately 100 times less soluble than poorly crystalline Fe(III) arsenates [39].

\subsection{Microbial community dynamics}

T-RFLP analysis of our samples yielded unique community profiles; the communities in extremely metal-rich sediments were clearly different from those in the sediments with relatively low concentrations of metals (Fig. 5). The graphic MDS output based on Bray-Curtis similarities of bacterial communities indicated that the community profiles were clearly different for SCH and SCL. This result suggests that the concentrations of toxic metal ions might play an important role in microbial community 
composition. Moreover, although the samples for microbial community analysis were collected from weathered mine tailings in which the distance between SCH and SCL was less than $5 \mathrm{~cm}$, T-RFLP and clone library construction showed different microbial community compositions between two distinct sediments. Thus, the specific microbial community appears to be localized and heterogeneously distributed over relatively small spatial scales.

Sequence analysis by amplicon library construction also showed that the SCH bacterial communities with high concentrations of metals were distinctly different from the SCL communities with low metals (Fig. 6). In fact, except for one sequence identified as unclassified bacteria, no sequences in $\mathrm{SCH}$ overlapped with those in SCL; this is consistent with the extent of separation between SCH and SCL in the MDS plot (Fig. 5). The sequences identified in SCL were closely related to acidophilic bacterial 16S rRNA genes, including Granulicella and $\mathrm{Gp} 1$ in the phylum of Acidobacteria (32\%), Acidomicrobineae in the family of Actinobacteria (14\%), and Leptospirillum in the genus of Nitrospira $(10 \%)$ - not a surprising result, as the $\mathrm{pH}$ in SCL-2 was 2.49. Strains of Granulicella shown to be acidophilic and psychrotolerant have been idenfied in various environments including acidic peat bogs [40]. Leptospirillum sp. (e.g. L. ferrooxidans) are considered to be important in controlling the production rate of acid mine drainage [41].

Unlike SCL, only two genera were identified in SCH (Fig. 6); the clones identified in the sediments with high levels of toxic metals were closely related to the alphaproteobacterium Methylobacterium (79\%) and the betaproteobacterium Ralstonia (19\%). Previous studies showed that many bacterial species can tolerate toxic metals. For example, members of the genera Methylobacterium and Ralstonia were considered responsible for As(III) oxidation or As(V) reduction [42]. Methylobacterium has been isolated from woodland soil and leaf litter samples [43] and the rhizosphere of the As hyperaccumulator Pteris vittata [3]. Isolates close to Methylobacterium sp. showed resistance to

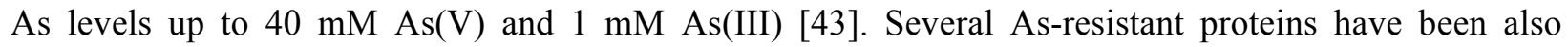
isolated from Methylobacterium [43]. In addition, some Methylobacterium isolates (e.g., $M$. 
organophilum, M. mesophilicum, M. extorquens, and M. sp. strain iEII3) exhibited varied resistance to Ni, $\mathrm{Cd}, \mathrm{Co}, \mathrm{Zn}$, and $\mathrm{Cr}$ [44, 45], with minimum inhibitory concentrations (MIC) of 1-12 mM for Ni, 1-2 mM for $\mathrm{Cd}, 1-3 \mathrm{mM}$ for $\mathrm{Co}, 2-15 \mathrm{mM}$ for $\mathrm{Zn}$, and $1 \mathrm{mM}$ for $\mathrm{Cr}$ [44]. Methylotrophic bacteria are known to use one-carbon compounds (e.g., methane, methanol, and other methylated compounds) as the carbon and energy sources for growth [46]. Thus, the predominance of Methylobacterium species (79\%) suggests that organo-metal (or organo-metalloid) compounds might be presented in $\mathrm{SCH}$ sediments. For example, organo-As compounds (e.g., mono-, di-, tri-methyl As compounds) are known to be formed via methylation of inorganic As by microorganisms and via enzymatic processes related to vitamin B12 [47].

Ralstonia spp. are also well known to be highly resistant to various heavy metals [48] and have been found in extreme environments, including industrial sediments, soils, or wastes with high levels of heavy metals $[48,49]$. For example, $R$. metallidurans $\mathrm{CH} 34$ discovered in the sediments of a $\mathrm{Zn}$ decantation basin in Belgium showed high resistance to $\mathrm{Zn}, \mathrm{Cd}, \mathrm{Co}, \mathrm{Ni}, \mathrm{Cu}, \mathrm{Cr}, \mathrm{Hg}$, and $\mathrm{Pb}$ [48]. A putative As resistance gene (ars $\mathrm{C})$ and $\mathrm{Pb}$ resistance genes have also been identified in $R$. solanacearum [50] and R. metallidurans [48, 51], respectively.

The substantial differences in the concentrations of toxic metals between SCH and SCL suggest that the unique community compositions are likely due to the sheer stress of the toxic metals in SCH and SCL. Although As is the most abundant toxic compound in the samples and Methylobacterium and Ralstonia are known to be resistant to As, many studies report that $\mathrm{As}(\mathrm{V})$ at concentrations $<1000 \mathrm{mg} \mathrm{L}^{-1}$ does not inhibit bacterial growth. The data in the current study show that As was present as approximately $10 \%$ of the solids in SCH-2, but only $0.12 \%$ of that leached out in solution. In addition, most of the As was present as $\operatorname{As}(\mathrm{V})$ (i.e., $95 \%>$ scorodite), and the area has been exposed to the air for a long time. Therefore, the high levels of As in the weathered mine tailings are likely not the dominant factor for enriching the bacterial community in species capable of tolerating this extreme environment.

The diversity of the archaeal community in SCL was quite simple compared to that of the bacterial community (Fig. 6). Since the concentrations of acid-extractable metal ions were relatively low 
(Table 2), the low diversity of the archaeal community is likely not due to toxic metal ion concentrations. Instead, it might result from the smaller set of archaeal sequences than bacterial sequences. In spite of many attempts to amplify archaeal genomic DNA from the $\mathrm{SCH}$ sediment with high toxic metal content, we failed with the sequences related to archaea with universal AR primers, which are known to be very effective for amplification of archaeal sequences [52]. Therefore, archaea might not be abundant in the sediment with high levels of toxic metals, although many previous studies reported that archaea can proliferate in extreme environments like the sediments examined in this study.

\subsection{Factors controlling microbial community compositions}

Several factors likely control the microbial community composition in Songcheon weathered mine tailings. First, the particle size distribution might affect differences in microbial community compositions between SCH and SCL samples. The proportion of fine particles (silt + clay) is higher in SCH than in SCL (Table 1). Piotrowska-Seget et al. [45] investigated the metal-tolerant populations from arable soils of different textures and barren spoil near an Ag mine and found differences in the bacterial populations between sandy-loam and clay soils. Subsurface materials with fine particles such as clays might create local anoxic conditions and set up physical constraints or barriers to microbial transport, resulting in localization of specific microbial communities. However, the effects of particle size on community differences were not clear, as the clay soil included higher concentrations of heavy metals [45].

Second, toxic metal ions might affect community composition, as SCH and SCL showed significant differences in total and acid-extractable metal fractions. Identifying the specific metals playing a determining role in creating such distinct community compositions is difficult, however, because even small concentrations of toxic metals can have long-term effects on microbial metabolism and growth. Nevertheless, the speciation and concentration of As likely did not affect microbial community composition, because As was present mostly as $\mathrm{As}(\mathrm{V})(>95 \%)$, which does not influence bacterial growth 
at concentrations up to $1000-10000 \mathrm{mg} \mathrm{L}^{-1}$ [53-55] (Table S2). The effects of $\mathrm{Cu}$ and $\mathrm{Ni}$ on microorganisms might be minimal, as acid-extractable concentrations of these metals were at levels found not to inhibit E. coli [56], Desulfovibrio desufuricans [57], and Yarrowia lipolytica [58].

$\mathrm{Pb}$ and/or $\mathrm{Zn}$ might be the most significant factors determining differences in microbial community composition between SCH and SCL samples. Past studies indicate that MIC of Pb were as low as $2 \mathrm{mg} \mathrm{L}^{-1}$ [59] and $21 \mathrm{mg} \mathrm{L}^{-1}$ [60] for D. desulfuricans and Bacillus megaterium, respectively (Table S2). In the case of Zn, the LC50 (lethal concentration, 50\%) for yeast $Y$. lipolytica and MIC for $E$. coli were as low as $118 \mathrm{mg} \mathrm{L}^{-1}$ [58] and $65 \mathrm{mg} \mathrm{L}^{-1}$ [61], respectively. Therefore, F1 concentrations of $\mathrm{Pb}$ and $\mathrm{Zn}$ in $\mathrm{SCH}$ (280 and $192 \mathrm{mg} \mathrm{kg}^{-1}$, respectively) might be toxic to indigenous microbial populations. In addition, the high abundance of Methylobacterium and Ralstonia - highly $\mathrm{Pb}$ and $\mathrm{Zn}$ tolerant betaproteobacteria $[45,48,61,62]$ - might be the result of strong selective pressure against less tolerant populations in the SCH sediments.

Although our results do not provide sufficient information to determine which factors played the most critical role(s) in microbial community composition, they do suggest that extreme geochemical conditions, particularly high concentrations of toxic metals, in the mine tailings drive the development of distinct microbial communities.

Our results also suggest that the practice of homogenizing a soil core prior to chemical analysis and/or DNA extraction may provide an inaccurate assessment of the soil by obscuring the heterogeneous distribution of key soil properties; care should be taken when analyzing soils particularly near mine tailings, because large differences in chemical and biological characteristics can be observed even on small spatial scales.

\section{Conclusions}

The effects of toxic metals on microbial community composition in the weathered mine tailings were investigated with two distinct sets of sediments containing high (SCH) versus low (SCL) levels of 
toxic metals. Geochemical and mineralogical analyses, coupled with microbial community analysis, showed clear differences in concentrations of toxic metals and microbial community compositions between SCH and SCL, but major As-minerals were similar in both samples. Total concentrations of toxic metals were $\mathrm{As}>\mathrm{Pb}>\mathrm{Zn}>\mathrm{Cu}>\mathrm{Ni}$ in both $\mathrm{SCH}$ and SCL, while the concentrations of acidextractable (mostly water-soluble) metals were $\mathrm{Pb}>\mathrm{Zn}>\mathrm{As}>\mathrm{Cu}>$ Ni. The microbial community composition in SCH was much simpler than that in SCL and consisted mainly of the toxic-metal-resistant bacteria Methylobacterium and Ralstonia. Although total As in $\mathrm{SCH}$ was $\sim 10 \%$, acid-extractable As was only $118 \mathrm{mg} \mathrm{kg}^{-1}$, probably because of the presence of very insoluble As phases ( $>95 \%$ scorodite), as confirmed by X-ray absorption fine structure spectra. In addition, significant levels of $\mathrm{Pb}$ and $\mathrm{Zn}$ present as acid-extractable phases might play a critical role in community differences in these weathered mine tailings.

\section{Acknowledgement}

We thank Bhoopesh Mishra and Drew Latta for help during the EXAFS data collection and Karen Haugen for thoughtful editing of the manuscript. Research under the Subsurface Biogeochemical Research Program Scientific Focus Area at Argonne was supported by the Subsurface Biogeochemical Research Program, Office of Biological and Environmental Research, Office of Science (OS), U.S. Department of Energy (DOE), under contract DE-AC02-06CH11357, as was use of the Advanced Photon Source, a DOE-OS use facility operated by Argonne. MRCAT/EnviroCAT operations are supported by DOE and the member institutions. This work also was supported by KIST - Gangneung Institute (Grant no. 2Z04381) and Korea Ministry of Environment as The GAIA Project-2013000540005. 


\section{References}

[1] B.J. Alloway, Heavy metals in soils, Second edition, Blackie ; Halsted Press, Glasgow New York, 1995.

[2] F. Wolfe-Simon, J.S. Blum, T.R. Kulp, G.W. Gordon, S.E. Hoeft, J. Pett-Ridge, J.F. Stolz, S.M. Webb, P.K. Weber, P.C.W. Davies, A.D. Anbar, R.S. Oremland, A Bacterium That Can Grow by Using Arsenic Instead of Phosphorus, Science, 332 (2011) 1163-1166.

[3] A. Huang, M. Teplitski, B. Rathinasabapathi, L. Ma, Characterization of arsenic-resistant bacteria from the rhizosphere of arsenic hyperaccumulator Pteris vittata, Can. J. Microbiol., 56 (2010) 236-246.

[4] A. Sarkar, S. Kazy, P. Sar, Characterization of arsenic resistant bacteria from arsenic rich groundwater of West Bengal, India, Ecotoxicology, 22 (2013) 363-376.

[5] S. Silver, Bacterial resistances to toxic metal ions - a review, Gene, 179 (1996) 9-19.

[6] S. Silver, L.T. Phung, BACTERIAL HEAVY METAL RESISTANCE: New Surprises, Annu. Rev Microbiol., 50 (1996) 753-789.

[7] M. Paulsson, B. Nyström, H. Blanck, Long-term toxicity of zinc to bacteria and algae in periphyton communities from the river Göta Älv, based on a microcosm study, Aquat. Toxicol., 47 (2000) 243-257.

[8] G.R. Rout, P. Das, Effect of Metal Toxicity on Plant Growth and Metabolism: I. Zinc, Agronomie, 23 (2003) 3-11.

[9] P.S. Rainbow, S.N. Luoma, Metal toxicity, uptake and bioaccumulation in aquatic invertebratesModelling zinc in crustaceans, Aquat. Toxicol., 105 (2011) 455-465.

[10] C.A. McDevitt, A.D. Ogunniyi, E. Valkov, M.C. Lawrence, B. Kobe, A.G. McEwan, J.C. Paton, A Molecular Mechanism for Bacterial Susceptibility to Zinc, PLoS Pathog., 7 (2011) e1002357. 
[11] R.K. Sani, B.M. Peyton, L.T. Brown, Copper-Induced Inhibition of Growth of Desulfovibrio desulfuricans G20: Assessment of Its Toxicity and Correlation with Those of Zinc and Lead, Appl. Environ. Microbiol., 67 (2001) 4765-4772.

[12] F.S. Mowat, K.J. Bundy, Experimental and mathematical/computational assessment of the acute toxicity of chemical mixtures from the Microtox ${ }^{\circledR}$ assay, Adv. Environ. Res., 6 (2002) 547-558.

[13] E. Fulladosa, J.-C. Murat, I. Villaescusa, Study on the toxicity of binary equitoxic mixtures of metals using the luminescent bacteria Vibrio fischeri as a biological target, Chemosphere, 58 (2005) $551-557$.

[14] H.L. Gough, D.A. Stahl, Microbial community structures in anoxic freshwater lake sediment along a metal contamination gradient, ISME J., 5 (2011) 543-558.

[15] J.-S. Lee, H.-T. Chon, K.-W. Kim, Human risk assessment of $\mathrm{As}, \mathrm{Cd}, \mathrm{Cu}$ and $\mathrm{Zn}$ in the abandoned metal mine site, Environ. Geochem. Hlth., 27 (2005) 185-191.

[16] G. Rauret, J.F. López-Sánchez, A. Sahuquillo, R. Rubio, C. Davidson, A. Ure, P. Quevauviller, Improvement of the BCR three step sequential extraction procedure prior to the certification of new sediment and soil reference materials, J. Environ. Monitor., 1 (1999) 57-61.

[17] R.A. Sutherland, BCR ${ }^{\circledR}-701$ : A review of 10-years of sequential extraction analyses, Anal. Chim. Acta, $680(2010)$ 10-20.

[18] W.T. Liu, T.L. Marsh, H. Cheng, L.J. Forney, Characterization of microbial diversity by determining terminal restriction fragment length polymorphisms of genes encoding 16S rRNA, Appl. Environ. Microbiol., 63 (1997) 4516-4522.

[19] Z. Abdo, U.M.E. Schüette, S.J. Bent, C.J. Williams, L.J. Forney, P. Joyce, Statistical methods for characterizing diversity of microbial communities by analysis of terminal restriction fragment length polymorphisms of 16S rRNA genes, Environ. Microbiol., 8 (2006) 929-938. 
[20] J.R. Cole, Q. Wang, J.A. Fish, B. Chai, D.M. McGarrell, Y. Sun, C.T. Brown, A. Porras-Alfaro, C.R. Kuske, J.M. Tiedje, Ribosomal Database Project: data and tools for high throughput rRNA analysis, Nucleic Acids Res., (2013).

[21] R. Sutherland, Loss-on-ignition estimates of organic matter and relationships to organic carbon in fluvial bed sediments, Hydrobiologia, 389 (1998) 153-167.

[22] O. Heiri, A. Lotter, G. Lemcke, Loss on ignition as a method for estimating organic and carbonate content in sediments: reproducibility and comparability of results, J. Paleolimnol., 25 (2001) 101-110.

[23] S. Dudka, R. Ponce-Hernandez, G. Tate, T.C. Hutchinson, Forms of $\mathrm{Cu}, \mathrm{Ni}$, and $\mathrm{Zn}$ in soils of sudbury, ontario and the metal concentrations in plants, Water Air Soil Pollut., 90 (1996) 531542.

[24] A.J. Frierdich, J.G. Catalano, Distribution and speciation of trace elements in iron and manganese oxide cave deposits, Geochim. Cosmochim. Acta, 91 (2012) 240-253.

[25] S.C. Ying, B.D. Kocar, S. Fendorf, Oxidation and competitive retention of arsenic between iron- and manganese oxides, Geochim. Cosmochim. Acta, 96 (2012) 294-303.

[26] R.M. McKenzie, The Adsorption of Lead and Other Heavy Metals on Oxides of Manganese and Iron, Aust. J. Soil Res., 18 (1980) 61-73.

[27] J.A. Coston, C.C. Fuller, J.A. Davis, $\mathrm{Pb}^{2+}$ and $\mathrm{Zn}^{2+}$ adsorption by a natural aluminum- and ironbearing surface coating on an aquifer sand, Geochim. Cosmochim. Acta, 59 (1995) 3535-3547.

[28] K. Parida, P.K. Satapathy, N. Das, Studies on Indian Ocean Manganese Nodules: IV. Adsorption of Some Bivalent Heavy Metal Ions onto Ferromanganese Nodules, J. Colloid Interf. Sci., 181 (1996) 456-462.

[29] W.C. Lee, Y.H. Kim, H.G. Cho, S.O. Kim, Characterization on the Behavior of Heavy Metals and Arsenic in the Weathered Tailings of Songcheon Mine, Journal of Mineralogical Society of Korea (Korean), 23 (2010) 125-139. 
[30] A. Foster, R. Ashley, J. Rytuba, Arsenic species in weathering mine tailings and biogenic solids at the Lava Cap Mine Superfund Site, Nevada City, CA, Geochem. T., 12 (2011) 1.

[31] M.C. Corriveau, H.E. Jamieson, M.B. Parsons, G.E.M. Hall, Mineralogical characterization of arsenic in gold mine tailings from three sites in Nova Scotia, Geochem-Explor. Env A., 11 (2011) 179-192.

[32] A. Murciego, E. Álvarez-Ayuso, E. Pellitero, M.A. Rodríguez, A. García-Sánchez, A. Tamayo, J. Rubio, F. Rubio, J. Rubin, Study of arsenopyrite weathering products in mine wastes from abandoned tungsten and tin exploitations, J. Hazard. Mater., 186 (2011) 590-601.

[33] T. Fujita, S. Fujieda, K. Shinoda, S. Suzuki, Environmental leaching characteristics of scorodite synthesized with Fe(II) ions, Hydrometallurgy, 111-112 (2012) 87-102.

[34] J.S. Rieuwerts, K. Mighanetara, C.B. Braungardt, G.K. Rollinson, D. Pirrie, F. Azizi, Geochemistry and mineralogy of arsenic in mine wastes and stream sediments in a historic metal mining area in the UK, Sci. Total Environ., 472 (2014) 226-234.

[35] D. Langmuir, J. Mahoney, J. Rowson, Solubility products of amorphous ferric arsenate and crystalline scorodite $\left(\mathrm{FeAsO}_{4} \cdot 2 \mathrm{H}_{2} \mathrm{O}\right)$ and their application to arsenic behavior in buried mine tailings, Geochim. Cosmochim. Acta, 70 (2006) 2942-2956.

[36] D. Paktunc, K. Bruggeman, Solubility of nanocrystalline scorodite and amorphous ferric arsenate: Implications for stabilization of arsenic in mine wastes, Appl. Geochem., 25 (2010) 674-683.

[37] Y. Zhu, B. Merkel, The dissolution and solubility of scorodite, $\mathrm{FeAsO}_{4} \cdot \mathrm{H}_{2} \mathrm{O}-$ Evaluation and simulation with PHREEQC, Wiss. Mitt. Inst. Geol. TU BAF, 18 (2001) 72-87.

[38] M.C. Harvey, M.E. Schreiber, J.D. Rimstidt, M.M. Griffith, Scorodite Dissolution Kinetics: Implications for Arsenic Release, Environ. Sci. Technol., 40 (2006) 6709-6714.

[39] M.-C. Bluteau, G.P. Demopoulos, The incongruent dissolution of scorodite — Solubility, kinetics and mechanism, Hydrometallurgy, 87 (2007) 163-177. 
[40] T.A. Pankratov, S.N. Dedysh, Granulicella paludicola gen. nov., sp. nov., Granulicella pectinivorans sp. nov., Granulicella aggregans sp. nov. and Granulicella rosea sp. nov., acidophilic, polymer-degrading acidobacteria from Sphagnum peat bogs, Int. J. Syst. Evol. Micr., 60 (2010) 2951-2959.

[41] M.O. Schrenk, K.J. Edwards, R.M. Goodman, R.J. Hamers, J.F. Banfield, Distribution of Thiobacillus ferrooxidans and Leptospirillum ferrooxidans: Implications for Generation of Acid Mine Drainage, Science, 279 (1998) 1519-1522.

[42] F. Battaglia-Brunet, Y. Itard, F. Garrido, F. Delorme, C. Crouzet, C. Greffié, C. Joulian, A Simple Biogeochemical Process Removing Arsenic from a Mine Drainage Water, Geomicrobiol. J., 23 (2006) 201-211.

[43] C.R. Jackson, S.L. Dugas, K.G. Harrison, Enumeration and characterization of arsenate-resistant bacteria in arsenic free soils, Soil Biol. Biochem., 37 (2005) 2319-2322.

[44] R. Idris, M. Kuffner, L. Bodrossy, M. Puschenreiter, S. Monchy, W.W. Wenzel, A. Sessitsch, Characterization of Ni-tolerant methylobacteria associated with the hyperaccumulating plant Thlaspi goesingense and description of Methylobacterium goesingense sp. nov, Syst. Appl. Microbiol., 29 (2006) 634-644.

[45] Z. Piotrowska-Seget, M. Cycoń, J. Kozdrój, Metal-tolerant bacteria occurring in heavily polluted soil and mine spoil, Appl. Soil Ecol., 28 (2005) 237-246.

[46] L. Chistoserdova, M.G. Kalyuzhnaya, M.E. Lidstrom, The Expanding World of Methylotrophic Metabolism, Annu. Rev. Microbiol., 63 (2009) 477-499.

[47] R. Bentley, T.G. Chasteen, Microbial Methylation of Metalloids: Arsenic, Antimony, and Bismuth, Microbiol. Mol. Biol. R., 66 (2002) 250-271.

[48] M. Mergeay, S. Monchy, T. Vallaeys, V. Auquier, A. Benotmane, P. Bertin, S. Taghavi, J. Dunn, D. van der Lelie, R. Wattiez, Ralstonia metallidurans, a bacterium specifically adapted to toxic 
metals: towards a catalogue of metal-responsive genes, FEMS Microbiol. Rev., 27 (2003) 385410.

[49] J. Goris, P. De Vos, T. Coenye, B. Hoste, D. Janssens, H. Brim, L. Diels, M. Mergeay, K. Kersters, P. Vandamme, Classification of metal-resistant bacteria from industrial biotopes as Ralstonia campinensis sp. nov., Ralstonia metallidurans sp. nov. and Ralstonia basilensis Steinle et al. 1998 emend, Int. J. Syst. Evol. Micr., 51 (2001) 1773-1782.

[50] C. Jackson, S. Dugas, Phylogenetic analysis of bacterial and archaeal arsC gene sequences suggests an ancient, common origin for arsenate reductase, BMC Evol. Biol., 3 (2003) 18.

[51] B. Borremans, J.L. Hobman, A. Provoost, N.L. Brown, D. van der Lelie, Cloning and Functional Analysis of thepbr Lead Resistance Determinant of Ralstonia metallidurans CH34, J. Bacteriol., $183(2001) 5651-5658$.

[52] G.C. Baker, J.J. Smith, D.A. Cowan, Review and re-analysis of domain-specific 16S primers, J. Microbiol. Meth., 55 (2003) 541-555.

[53] S. Maeda, A. Ohki, K. Miyahara, T. Takeshita, S. Higashi, Growth characteristics and arsenic metabolism of two species of arsenic-tolerant bacteria, Appl. Organomet. Chem., 4 (1990) 245250.

[54] A.C. Anderson, A.A. Abdelghani, Toxicity of selected arsenical compounds in short term bacterial bioassays, Bull. Environ. Contam. Toxicol., 24 (1980) 124-127.

[55] M. Pepi, M. Volterrani, M. Renzi, M. Marvasi, S. Gasperini, E. Franchi, S.E. Focardi, Arsenicresistant bacteria isolated from contaminated sediments of the Orbetello Lagoon, Italy, and their characterization, J. Appl. Microbiol., 103 (2007) 2299-2308.

[56] B. Grey, T.R. Steck, Concentrations of Copper Thought To Be Toxic toEscherichia coli Can Induce the Viable but Nonculturable Condition, Appl. Environ. Microbiol., 67 (2001) 5325-5327.

[57] P.A. Loka Bharathi, V. Sathe, D. Chandramohan, Effect of lead, mercury and cadmium on a sulphate-reducing bacterium, Environ. Pollut., 67 (1990) 361-374. 
[58] M. Strouhal, R. Kizek, J. Vacek, L. Trnková, M. Němec, Electrochemical study of heavy metals and metallothionein in yeast Yarrowia lipolytica, Bioelectrochemistry, 60 (2003) 29-36.

[59] R.K. Sani, B.M. Peyton, M. Jandhyala, Toxicity of lead in aqueous medium to Desulfovibrio desulfuricans G20, Environ. Toxicol. Chem., 22 (2003) 252-260.

[60] T.M. Roane, Lead Resistance in Two Bacterial Isolates from Heavy Metal-Contaminated Soils, Microb Ecol, 37 (1999) 218-224.

[61] D.H. Nies, Heavy metal-resistant bacteria as extremophiles: molecular physiology and biotechnological use of Ralstonia sp. CH34, Extremophiles, 4 (2000) 77-82.

[62] T. Kunito, S. Shibata, S. Matsumoto, H. Oyaizu, Zinc Resistance of Methylobacterium Species, Biosci. Biotech. Bioch., 61 (1997) 729-731. 


\section{Figure Captions}

Figure 1. The study area and sampling sites, with the color difference between SCH and SCL samples (lower right).

Figure 2. Scanning electron micrographs of SCH-2 (A) and SCL-2 (B) samples.

Figure 3. XRD results for SCH-2 and SCL-2 samples

Figure 4. As K-edge XANES data for the soil samples and As(III) and As(V) standards, showing the predominance of $\mathrm{As}(\mathrm{V})$ in the samples.

Figure 5. Non-metric multi-dimensional scaling (MDS) plot of bacterial community differences between the samples with high and low metals levels in T-RFLP analyses. Distance between symbols scales with the dissimilarity among communities. Ovals indicate two distinct geochemical conditions (high versus low metal concentrations).

Figure 6. Microbial community composition at the genus level with 16S rRNA clone library analysis. SCH-Bac, bacterial community composition in the SCH-2 sample; SCL-Bac, bacterial community composition in the SCL-2 sample; SCL-Arch, archaeal community composition in the SCL-2 sample. The genus-unclassified clones were named according to their family, order, or class. Classification at phylum level (or class for Proteobacteria) in shown in parenthesis.

Table 1. Physical and chemical properties of samples from mine tailings and the background areas.

Table 2. Results of sequential extraction $\left(\mathrm{mg} \mathrm{kg}^{-1}\right)$. F1, acid extractable; F2, reducible; F3, oxidizable; F4, residual. 


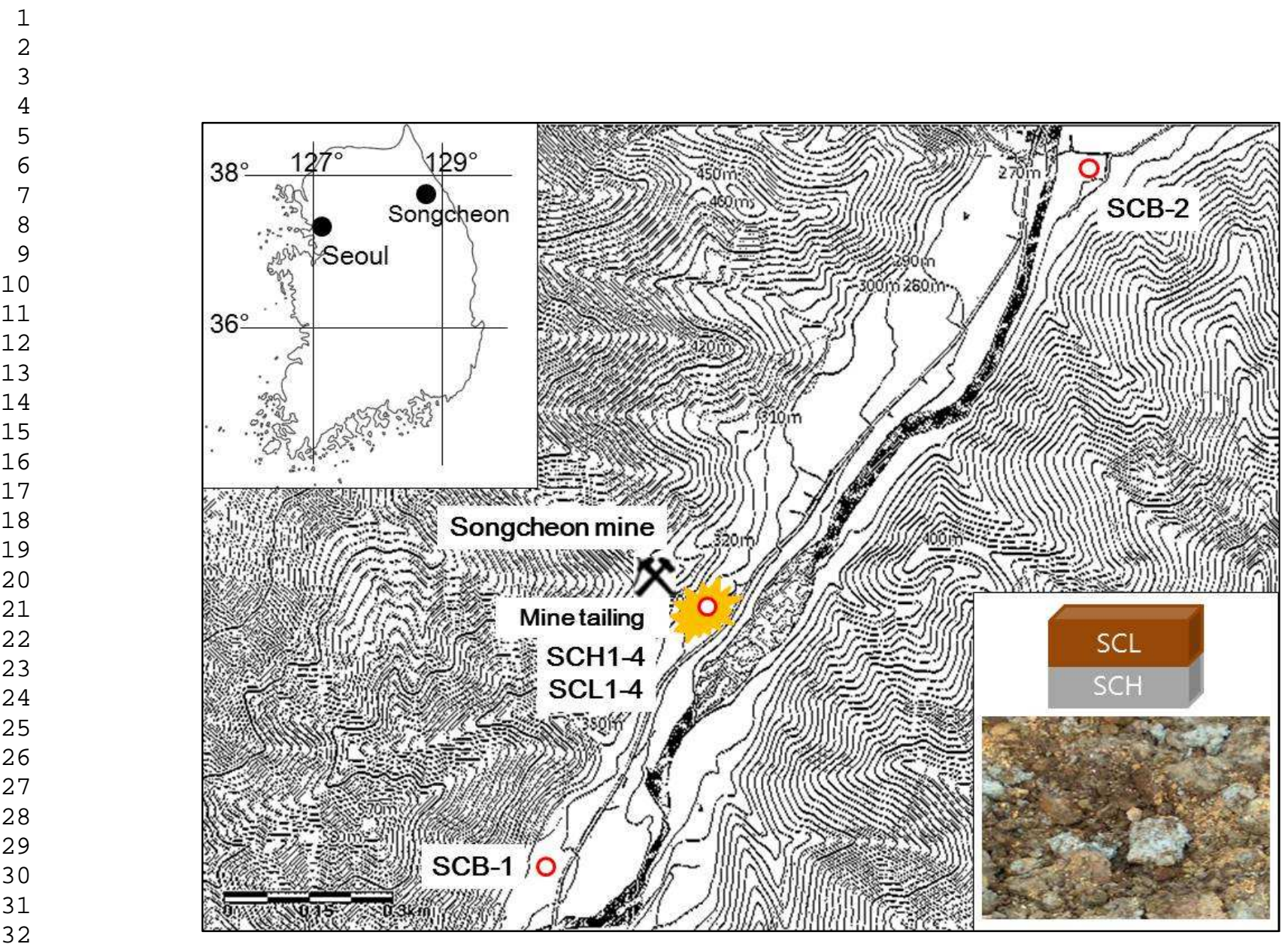

Figure 1. 


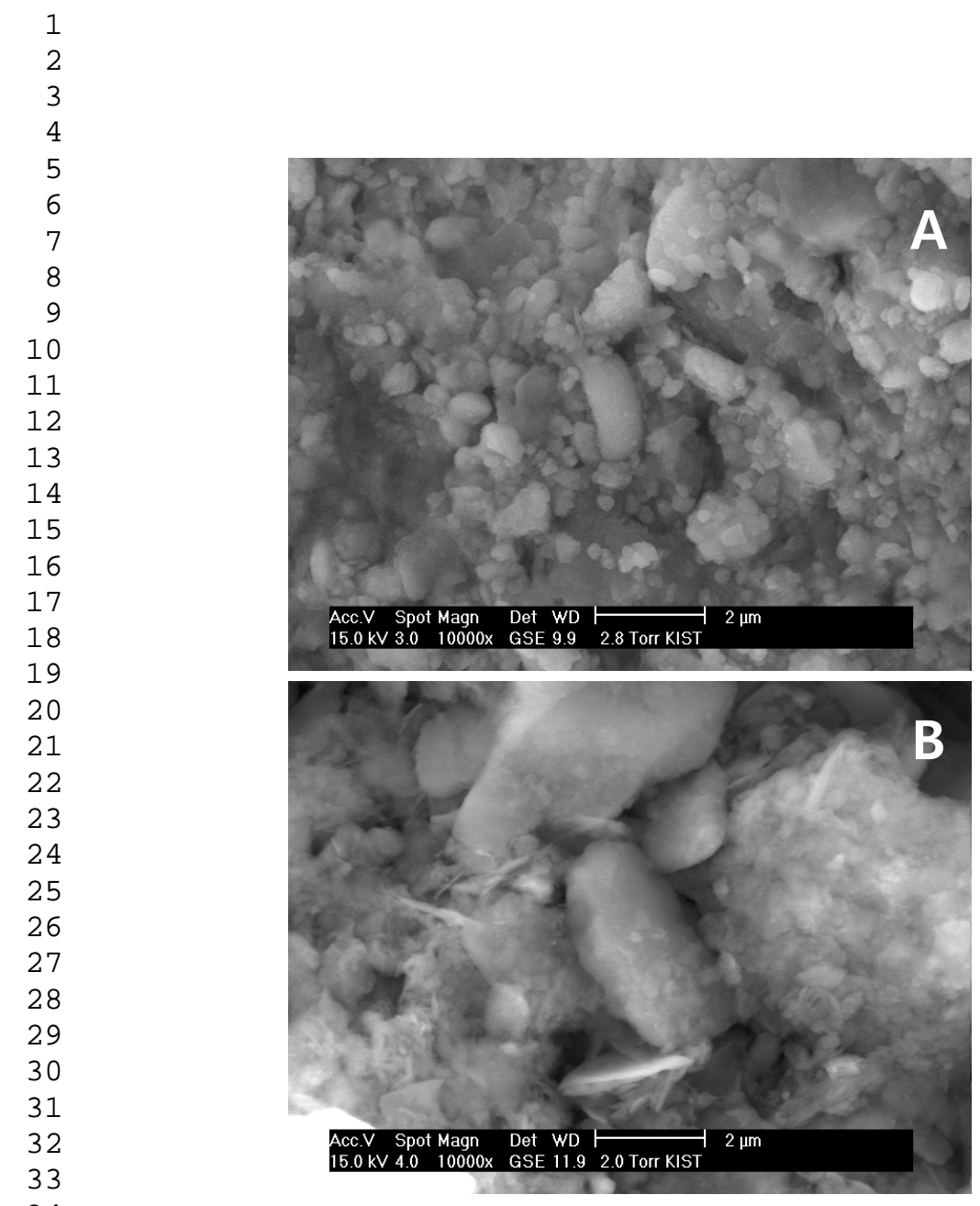

34

35

36

37

38

39

40

41

42

43

44

45

46

47

48

49

50

51

52

53

54

55

56

57

58

59

60

61

62

63

64

65

Figure 2. 


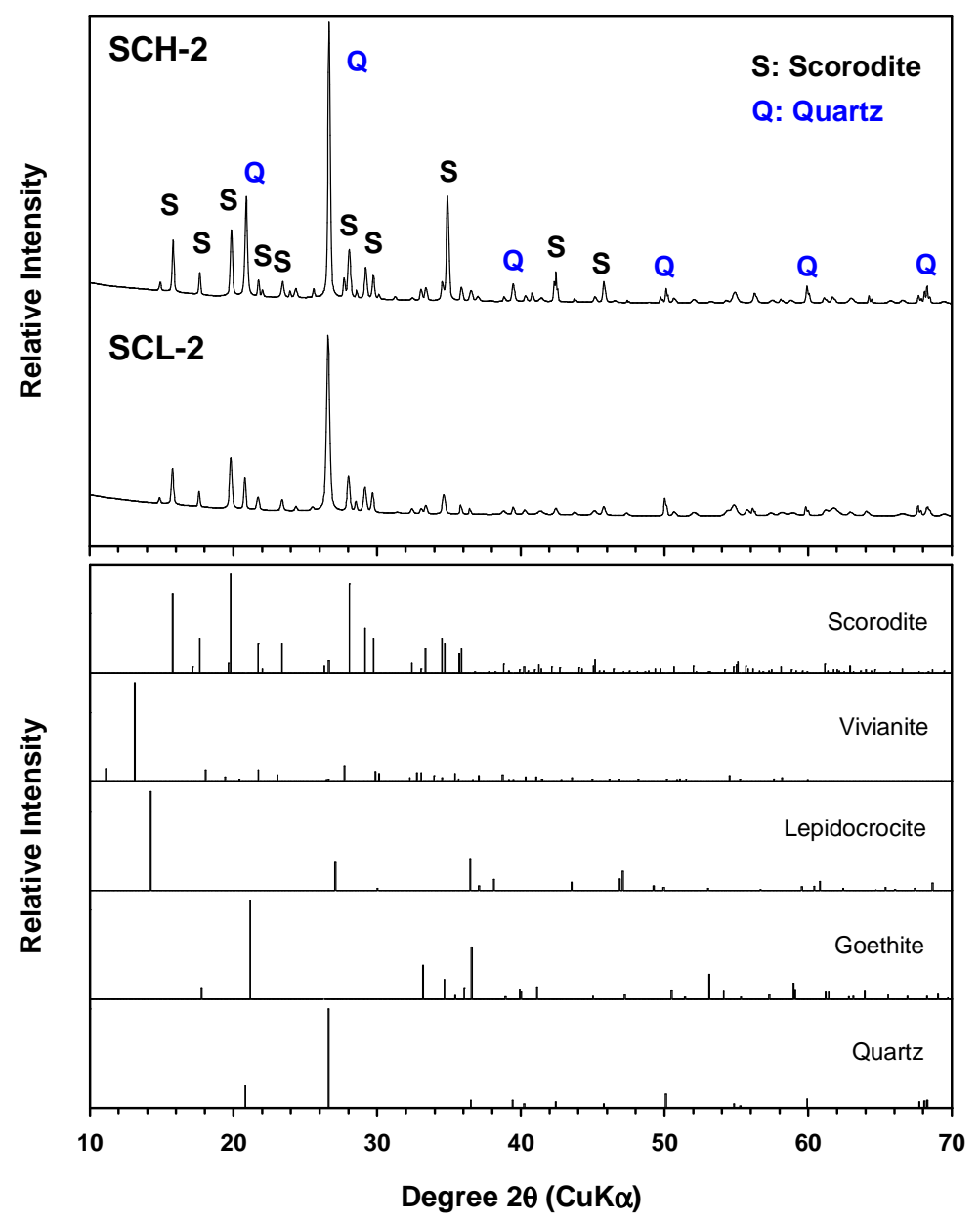

Figure 3. 


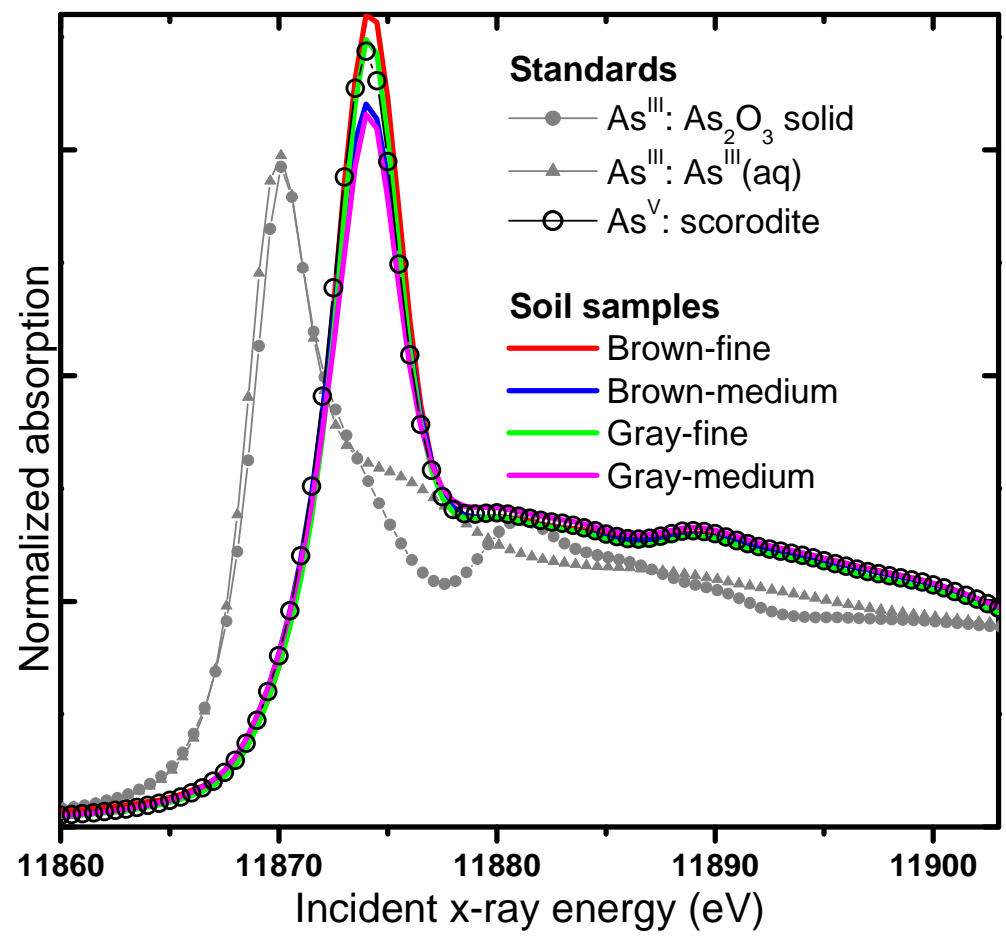

Figure 4. 


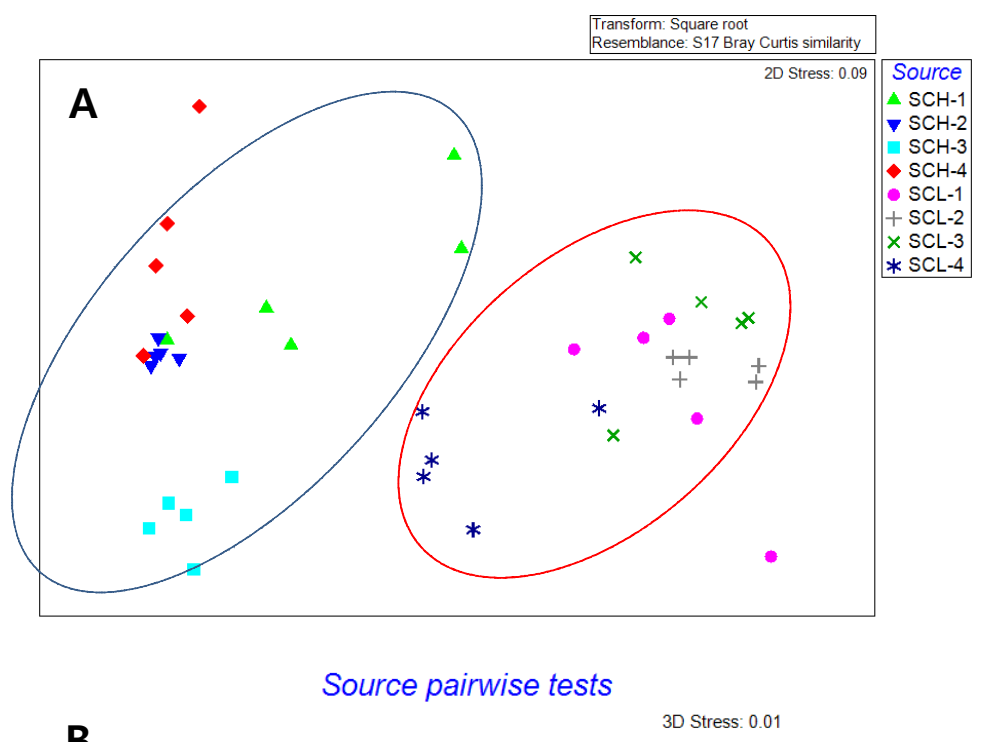

B

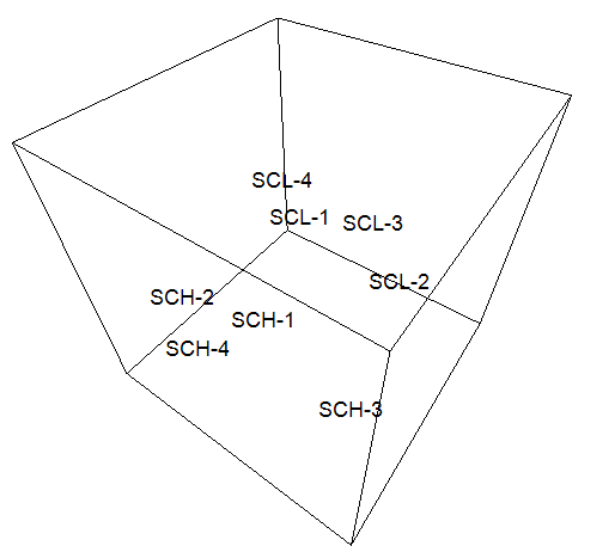

Figure 5.

42

43

44

45

46

47

48

49

50

51

52

53

54

55

56

57

58

59

60

61

62

63 


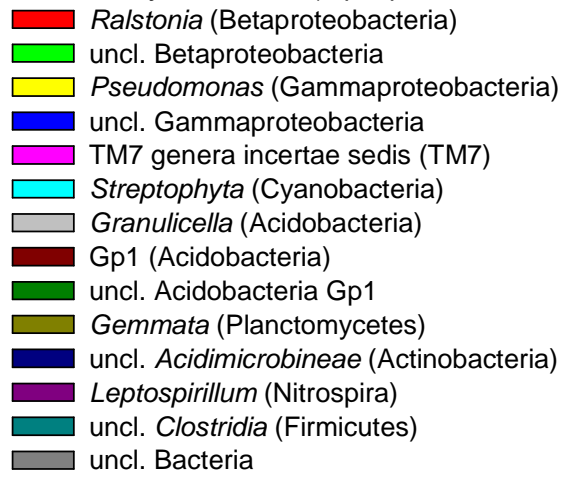

Figure 6 


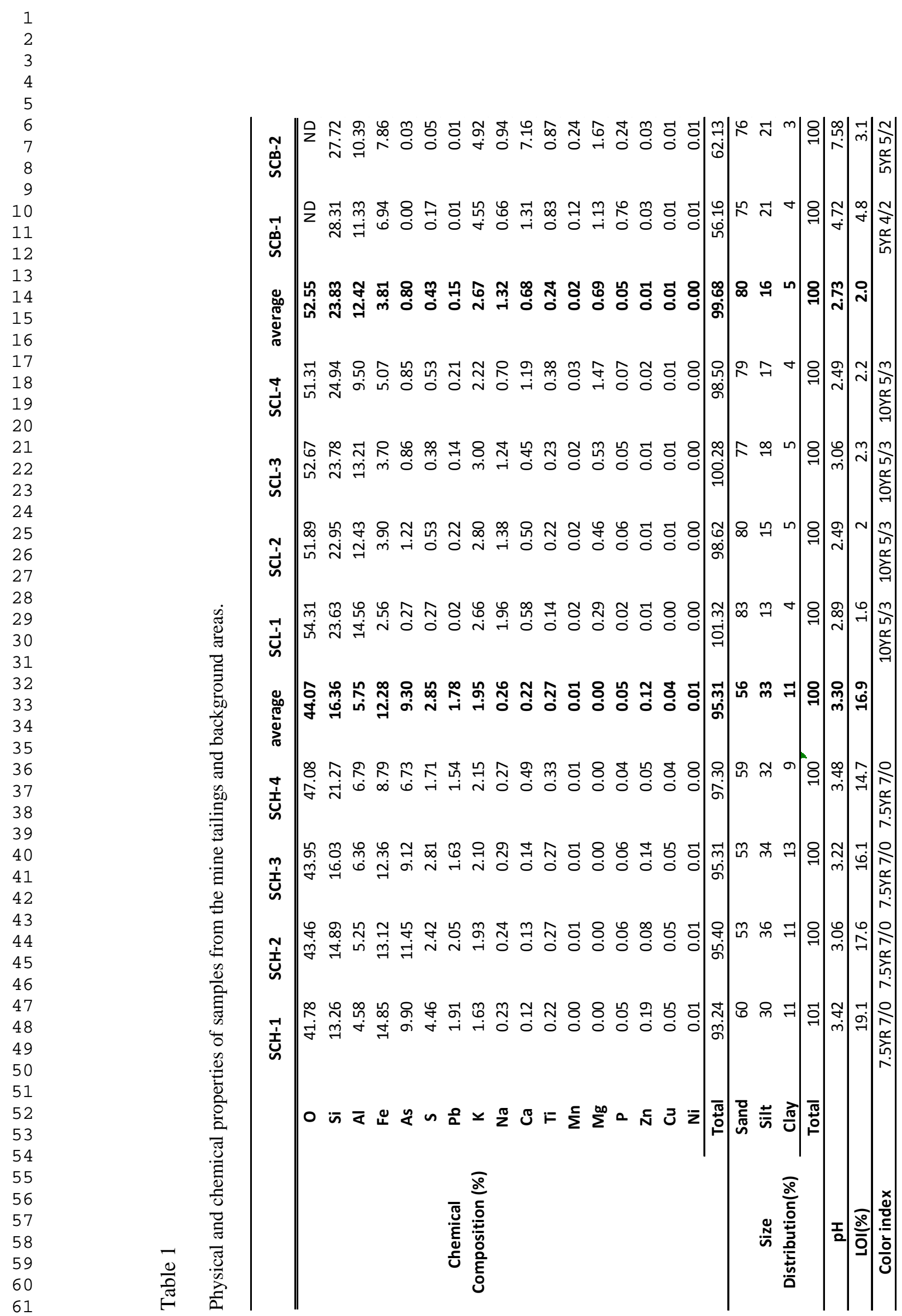

